University of Nebraska - Lincoln

DigitalCommons@University of Nebraska - Lincoln

Agronomy \& Horticulture -- Faculty Publications

Agronomy and Horticulture Department

$9-1-1997$

\title{
Predicting Developmental Morphology in Switchgrass and Big Bluestem
}

Rob B. Mitchell

Texas Tech University, rob.mitchell@ars.usda.gov

Kenneth J. Moore

lowa State University, kjmoore@iastate.edu

Lowell E. Moser

University of Nebraska-Lincoln, Imoser1@unl.edu

John O. Fritz

Kansas State University

Daren D. Redfearn

Louisiana State University, Agriculture Center, Southeast Research Station, dredfearn2@unl.edu

Follow this and additional works at: https://digitalcommons.unl.edu/agronomyfacpub

Part of the Plant Sciences Commons

Mitchell, Rob B.; Moore, Kenneth J.; Moser, Lowell E.; Fritz, John O.; and Redfearn, Daren D., "Predicting Developmental Morphology in Switchgrass and Big Bluestem" (1997). Agronomy \& Horticulture -- Faculty Publications. 67.

https://digitalcommons.unl.edu/agronomyfacpub/67

This Article is brought to you for free and open access by the Agronomy and Horticulture Department at DigitalCommons@University of Nebraska - Lincoln. It has been accepted for inclusion in Agronomy \& Horticulture -Faculty Publications by an authorized administrator of DigitalCommons@University of Nebraska - Lincoln. 


\title{
Predicting Developmental Morphology in Switchgrass and Big Bluestem
}

\author{
Rob B. Mitchell,* Kenneth J. Moore, Lowell E. Moser, John O. Fritz, and Daren D. Redfearn
}

\begin{abstract}
Switchgrass (Panicum virgatum L.) and big bluestem (Andropogon gerardii Vitman) are important warm-season grasses in livestock production systems in the central and eastern USA. The objectives of this study were to quantify the morphological development of 'Trailblazer' switchgrass and 'Pawnee' big bluestem and to evaluate day of the year (DOY) and growing degree day (GDD) as predictors of switchgrass and big bluestem morphological stage. Pure stands of each species were sampled at weekly intervals in 1990 and 1991 at Mead, NE, and classified as to mean stage count (MSC) and mean stage weight (MSW). Prediction equations for MSC and MSW were developed based on DOY and GDD. The validation study was harvested at 2-wk intervals in 1992 and 1993 at Mead, NE, and Manhattan, $\mathrm{KS}$, and classified as to MSC and MSW. Switchgrass and big bluestem MSC and MSW were related linearly in all environments. Linear DOY calibration equations accounted for $96 \%$ of the variation in switchgrass MSC across four environments, which indicates that switchgrass development was related to photoperiod and that general management recommendations could be based on DOY in the central Great Plains. Quadratic GDD calibration equations accounted for $83 \%$ of the variation in big bluestem MSC across four environments, which indicates that big bluestem development is more difficult to predict and management recommendations in the central Great Plains should be based on morphological development (which is best predicted by GDD). The comprehensive growth staging system gave repeatable results for quantifying the morphological development of switchgrass and big bluestem. The morphological development of switchgrass and big bluestem can be reliably predicted for adapted cultivars in the central Great Plains during years with near-normal precipitation using DOY and GDD because of the determinate growth habit of these grasses.
\end{abstract}

$\mathrm{S}$ ITCHGRASS AND BIG BLUESTEM are perennial, warmseason grasses native to the central Great Plains of the USA, and are determinate in growth habit. Switchgrass and big bluestem have become increasingly important as pasture grasses in the central and eastern USA because they are productive during the hot summer months, when cool-season grasses are relatively unproductive (Moser and Vogel, 1995). Cumulative effects of genetics, environment, and plant age are integrated and expressed in the developmental morphology of a species (Buxton and Marten, 1989). Morphological development has been used to time properly the application of management practices such as grazing (Kirch, 1995), hay harvesting (Kalu and Fick, 1981), prescribed

R.B. Mitchell, Dep. of Range, Wildlife, and Fisheries Management, Texas Tech Univ., Lubbock, TX 79409; K.J. Moore, Dep. of Agronomy, Iowa State Univ., Ames, IA 50011; L.E. Moser, Dep. of Agronomy, Univ. of Nebraska, Lincoln, NE 68583; J.O. Fritz, Dep. of Agronomy, Kansas State Univ., Manhattan, KS 66506; and D.D. Redfearn, LSU Agric. Ctr., Southeast Res. Stn., Franklinton, LA, 70438. Joint contribution of the Univ. of Nebraska, Lincoln Agric. Res. Div., Journal Series no. 11688, and Kansas State Univ., Dep. of Agronomy, Contribution no. 96-116-J. Received 23 Sept. 1996. *Corresponding author (c7mrb@ttacs.ttu.edu).

Published in Agron. J. 89:827-832 (1997). burning (Mitchell et al., 1994), and fertilization (Rehm et al., 1976).

Plant maturity is the primary factor affecting morphological development and forage quality within a species (Nelson and Moser, 1994). Morphological development influences accessibility, palatability, and regrowth potential of forage species following defoliation (Briske, 1991). Day of the year and accumulated GDD have been used to predict leaf development of native, warmseason grasses (Frank and Hofmann, 1989). Predicting the morphological development of a species may aid in planning and making forage management decisions.

A classification system developed by Moore et al. (1991) was used to quantify the relationship of MSC and MSW with DOY and GDD in prairie sandreed [Calamovilfa longifolia (Hook.) Scribn.] and sand bluestem [Andropogon gerardii var. paucipilus (Nash) Fern.] tiller populations (Hendrickson, 1992). The MSC of prairie sandreed and sand bluestem was predicted by DOY as well as by GDD. However, temporal and spatial variations in the morphological development of a sward may make MSC difficult to predict from one growing season to the next (Hendrickson, 1992; Moore and Moser, 1995).

Our objectives were (i) to quantify the developmental morphology and determine the relationship between MSC and MSW of switchgrass and big bluestem tiller populations and (ii) to evaluate DOY and GDD models as predictors of morphological development (MSC and MSW) of switchgrass and big bluestem tiller populations in different environments.

\section{MATERIALS AND METHODS}

\section{Prediction Equation Development}

Pure stands of 'Trailblazer' switchgrass and 'Pawnee' big bluestem were seeded in 1986 in a randomized complete block design with a split-plot arrangement and six replicates on a Sharpsburg silty clay loam soil (fine, montmorillonitic, mesic Typic Argiudoll) at the University of Nebraska Agricultural Research and Development Center near Mead, NE (96 $33^{\prime}$ $\left.\mathrm{W}, 41^{\circ} 11^{\prime} \mathrm{N}\right)$. Species were whole plots $(1.2$ by $4.6 \mathrm{~m})$, years (1990 and 1991) were subplots, and harvests were sub-subplots. Prior to initiation of spring growth each year, standing dead material was mowed to a $2-\mathrm{cm}$ stubble height and residue was removed. Nitrogen was applied in late May 1990 and 1991 at $110 \mathrm{~kg} \mathrm{~N} \mathrm{ha}^{-1}$. Switchgrass and big bluestem were harvested at approximately $7-\mathrm{d}$ intervals from two $0.09-\mathrm{m}^{2}$ quadrats, beginning on 6 June and concluding 6 Sept. 1990, and beginning on 22 May and concluding 3 Sept. 1991.

Tillers used for morphological classification were handclipped at ground level from two $0.09-\mathrm{m}^{2}$ quadrats randomly located within each whole plot. Tillers were transported to the laboratory and morphologically classified using the system described by Moore et al. (1991). The quantitative indices for

Abbreviations: DOY, day of the year; GDD, growing degree day; MSC, mean stage count; MSW, mean stage weight; RMSE, root mean square error; $S_{\mathrm{MSC}}$, standard deviation of the mean stage count. 
developmental stage were assigned at the conclusion of each growing season based on the total number of events in the vegetative and elongating stages. Mean stage count and MSW were determined for each species at each harvest date to quantify developmental morphology of the tiller populations using the working formula from Moore et al. (1991).

$$
\operatorname{MSC}=\sum_{i=1}^{4.9} \frac{S_{i} \times N_{i}}{C}
$$

where $S_{i}$ is the growth stage, 1 to $4.9 ; N_{i}$ is the number of tillers in stage $S_{i}$; and $C$ is the total number of tillers. The MSW can be calculated by replacing $N$ and $C$ with the total dry weight for the tillers in each stage and the total dry weight for all tillers, respectively. Standard deviation of the MSC $\left(S_{\mathrm{MSC}}\right)$ was determined for each species at each harvest date to estimate variation about the MSC within tiller populations using the following equation from Moore et al. (1991).

$$
S_{\mathrm{MSC}}=\sqrt{\sum_{i=1}^{4.9} \frac{\left(S_{i}-\mathrm{MSC}\right)^{2} \times N_{i}}{C}}
$$

Accumulated GDD for the $k$ th DOY was calculated as

$$
\mathrm{GDD}=\sum_{i=1}^{k} C_{i}-10
$$

where $C_{i}$ is the mean temperature for day $i$.

Day of the year and GDD were included as independent variables using linear, quadratic, and cubic effects with MSC and MSW as dependent variables in the combined data set for each species from 1990 and 1991 using the PROC REG procedure of SAS (SAS, 1985). Only significant $(P<0.10)$ regression coefficients were retained in the model.
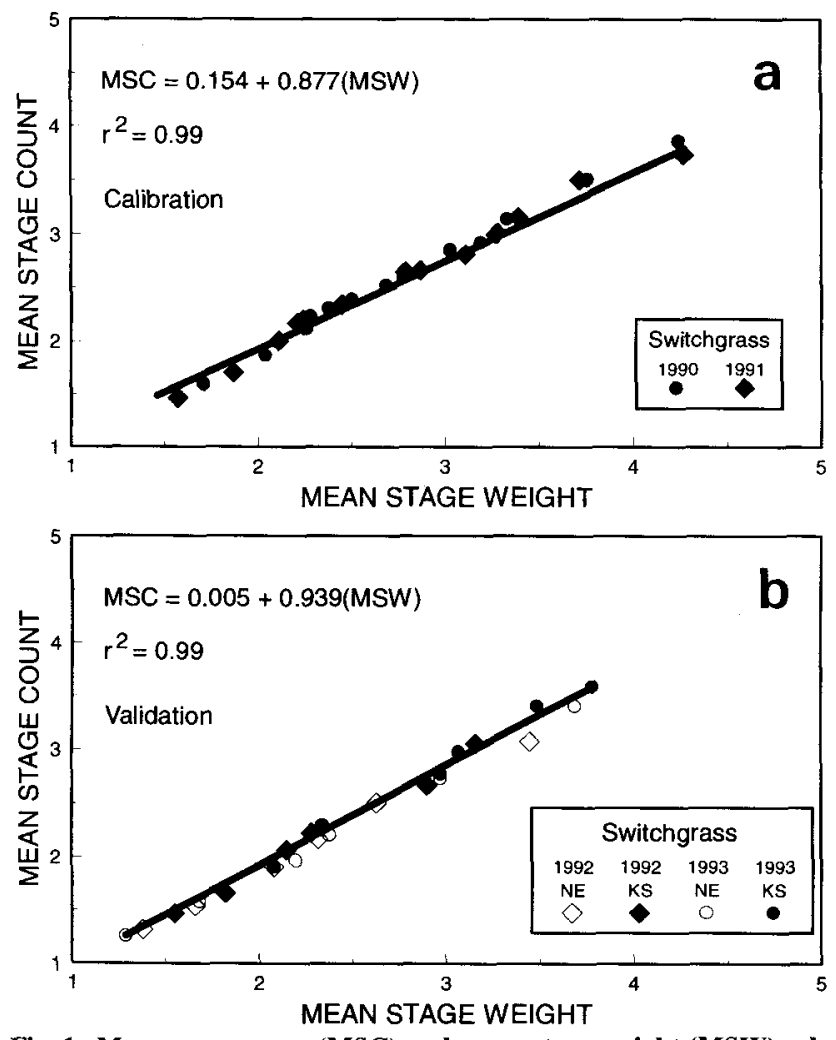

Fig. 1. Mean stage count (MSC) and mean stage weight (MSW) relationships for 'Trailblazer' switchgrass grown (a) near Mead, NE, in 1990 and 1991 and (b) near Mead, NE, and Manhattan, KS, in 1992 and 1993.

\section{Validation of Prediction Equations}

The validation study was conducted in 1992 and 1993 at the University of Nebraska Agricultural Research and Development Center near Mead and the Kansas State University Agronomy North Farm near Manhattan (96 33' W, 39 $11^{\prime} \mathrm{N}$ ). Validation plots of Trailblazer switchgrass and Pawnee big bluestem were established in 1991 on a Sharpsburg silty clay loam soil in Nebraska and on a Wymore silty clay loam soil (fine, smectitic, mesic Aquertic Argiudoll) in Kansas as randomized complete blocks arranged as split plots with three replicates. Species were whole plots, years (1992 and 1993) were subplots, and harvests (six per year) were sub-subplots. Whole plots were 5 by $10 \mathrm{~m}$, subplots were 5 by $5 \mathrm{~m}$, and subsubplots were 1.7 by $2.5 \mathrm{~m}$. Vegetation on the plots to be harvested in 1993 remained undisturbed throughout the 1992 growing season. Prior to initiation of spring growth, standing dead material was mowed to a $2-\mathrm{cm}$ stubble height and residue removed. Nitrogen was applied in late May 1992 and 1993 at $110 \mathrm{~kg} \mathrm{~N} \mathrm{ha}{ }^{-1}$. In Nebraska, switchgrass and big bluestem were harvested on 20 May, 3 and 17 June, 2 and 14 July, and 12 Aug. 1992 and 1993. In Kansas, switchgrass and big bluestem were harvested on 19 May, 4 and 19 June, 1 and 14 July, and 10 Aug. 1992, 10 and 25 June, 12 and 22 July, and 6 and 18 Aug. 1993. Tillers used for morphological classification were hand-clipped and morphologically classified as to MSC and MSW in the same manner as for the calibration study.

Mean stage count and MSW were predicted using the regression equations for DOY and GDD developed from the calibration study. Predicted MSC and MSW were regressed against the actual MSC and MSW determined from the validation study for each species across environments using PROC
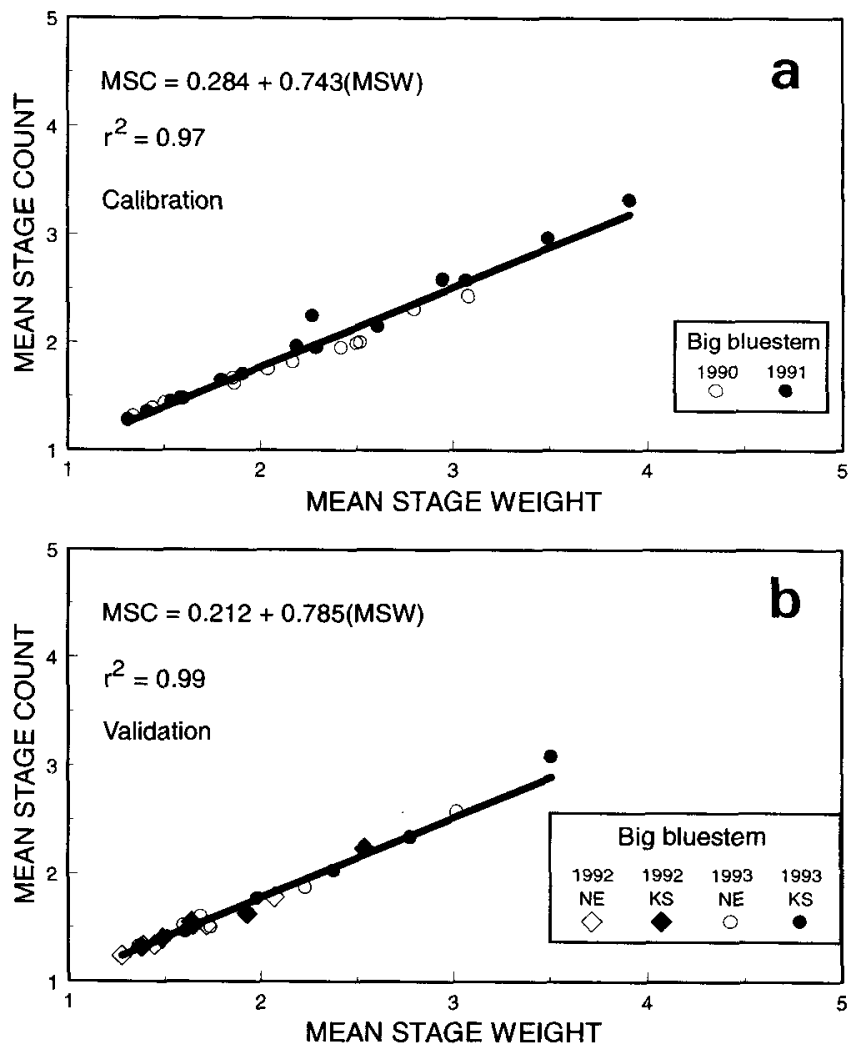

Fig. 2. Mean stage count (MSC) and mean stage weight (MSW) relationships for 'Pawnee' big bluestem grown (a) near Mead, NE, in 1990 and 1991 and (b) near Mead, NE, and Manhattan, KS, in 1992 and 1993. 
REG (SAS, 1985). The validity of each model was determined by evaluating the coefficient of determination, root mean square error (RMSE), slope, and intercept of the regression line describing the relationship between the predicted and actual MSC and MSW values.

\section{RESULTS AND DISCUSSION}

\section{Environmental Conditions}

Accumulated GDD on a given DOY was greater in 1991 than in 1990. Accumulated GDD patterns in Nebraska were similar throughout the growing season in 1992 and 1993. Accumulated GDD at the conclusion of sampling in 1992 and 1993 were $15 \%$ greater in Kansas than in Nebraska.

Long-term average annual precipitation at Mead is $680 \mathrm{~mm}$, with $500 \mathrm{~mm}$ occurring between 1 April and 1 October. Annual precipitation at Mead was near to or exceeded the 30-yr long-term average in 1990, 1991, 1992, and 1993 (totaling 687, 780, 658, and $859 \mathrm{~mm}$, respectively). At Manhattan, the long-term average annual precipitation is $860 \mathrm{~mm}$, with $600 \mathrm{~mm}$ occurring between 1 April and 1 October. Annual precipitation at Manhattan exceeded the long-term average in 1992 and 1993 (totaling 1053 and $1264 \mathrm{~mm}$, respectively).

\section{Developmental Morphology}

Switchgrass and big bluestem MSCs were linearly related to MSW in all environments (Fig. 1 and 2). However, MSC slightly underestimated MSW in both spe-
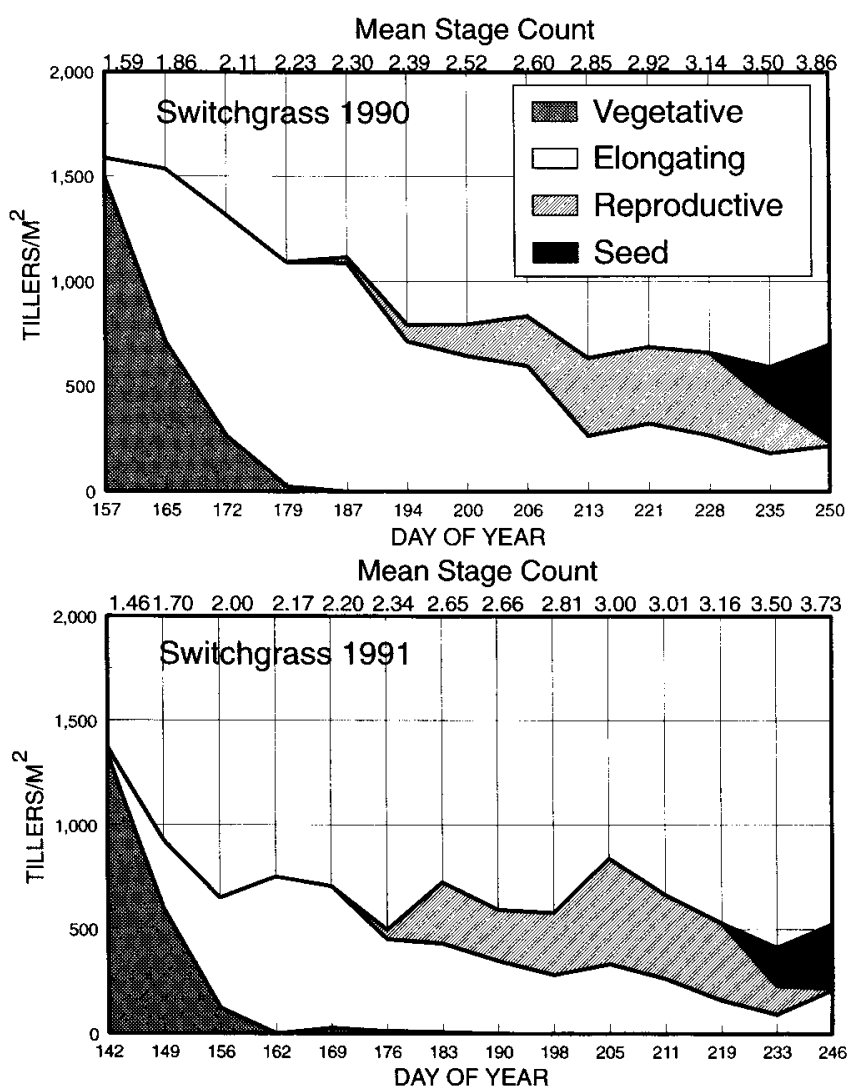

Fig. 3. Tiller demographics and mean stage counts for 'Trailblazer' switchgrass grown near Mead, NE, in 1990 and 1991. cies, as indicated by the slopes of the regression lines, particularly at later stages of development (Fig. 1 and 2 ). This indicates that MSW increased at a faster rate than did MSC, which is consistent with previous research with alfalfa (Medicago sativa L.) (Kalu and Fick, 1981) and with prairie sandreed and sand bluestem (Hendrickson, 1992). Since MSC is an average of all tillers present, the contribution of juvenile and mature tillers is equally weighted (Kalu and Fick, 1981). However, MSW is based on individual tiller weights. Because tillers accumulate dry matter as they mature, the MSW gives more leverage to tillers at advanced maturities (Moore et al., 1991). Since MSC and MSW were highly correlated and MSC is readily determined, quantification of developmental morphology for switchgrass and big bluestem will be presented as MSC.

Switchgrass developmental morphology progressed linearly with DOY and GDD in all environments. Big bluestem MSC increased linearly with DOY and quadratically with GDD in all environments. Switchgrass MSC was always greater than big bluestem MSC on common days of the year, indicating that switchgrass matured more rapidly. Switchgrass had a larger proportion of tillers develop to the seed production stage than big bluestem did, causing the greater MSC for switchgrass (Fig. 3 and 4). Few big bluestem tillers developed to the seed production stage prior to the completion of sampling, except in late 1991, as indicated by tiller demographics (Fig. 4).
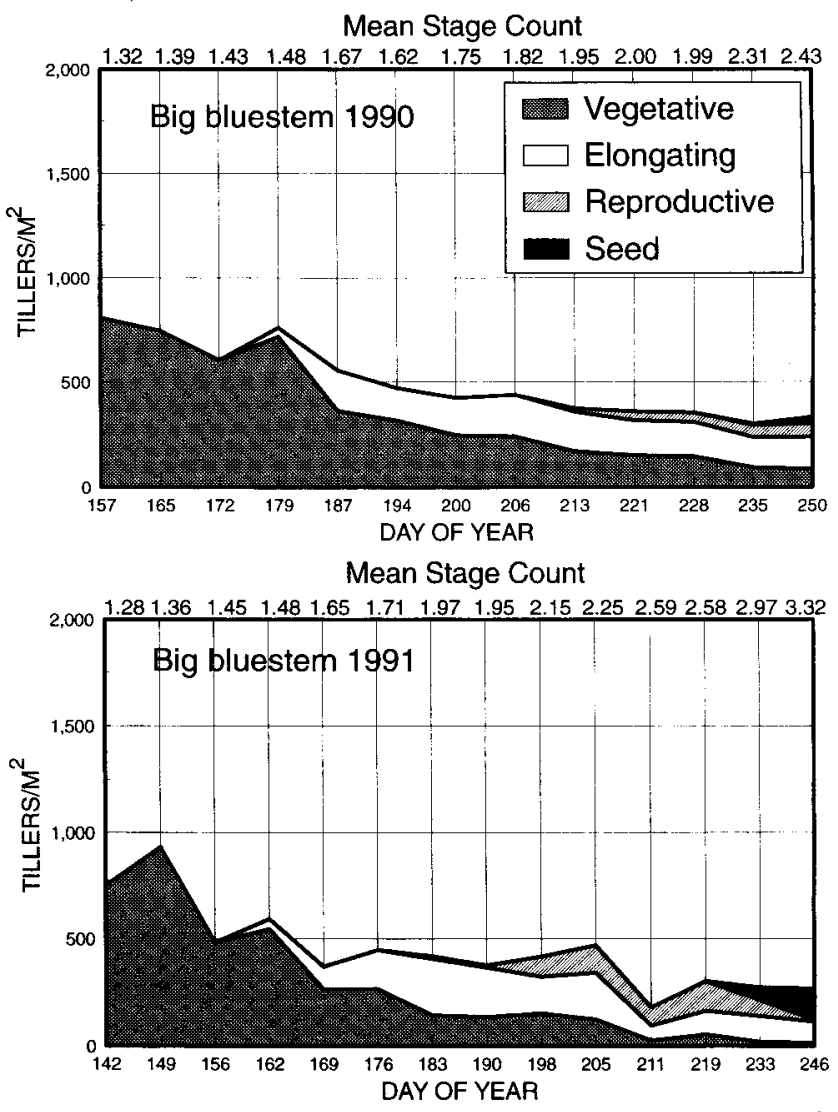

Fig. 4. Tiller demographics and mean stage counts for 'Pawnee' big bluestem grown near Mead, NE, in 1990 and 1991. 

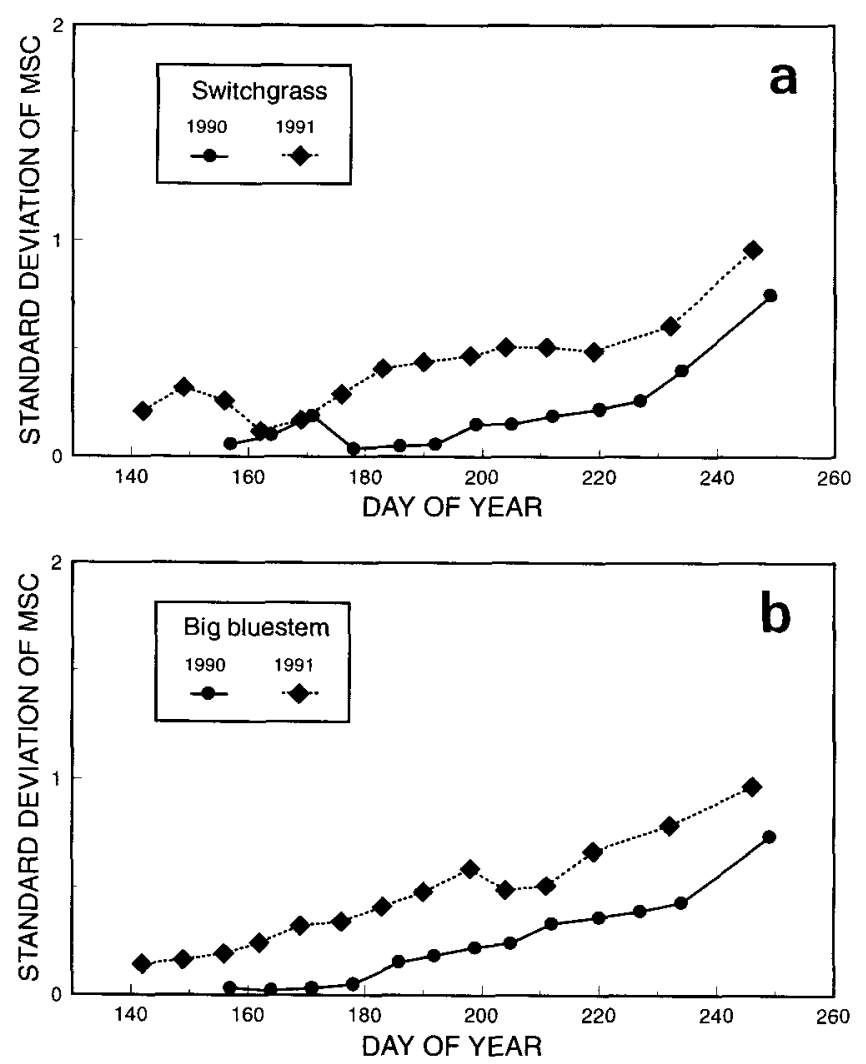

Fig. 5. Standard deviations of the mean stage count for (a) 'Trailblazer' switchgrass and (b) 'Pawnee' big bluestem grown near Mead, NE, in 1990 and 1991.

Switchgrass and big bluestem $S_{\mathrm{MSC}}$ increased in a similar manner as the growing season progressed at Mead, but $S_{\text {MSC }}$ was generally greater in 1991 than in 1990 (Fig. 5 ). The greater $S_{\mathrm{MSC}}$ in 1991 was probably a response to greater precipitation and more rapid accumulation of GDD. Big bluestem $S_{\mathrm{MSC}}$ was greater than switchgrass $S_{\mathrm{MSC}}$ in Kansas, whereas switchgrass and big bluestem $S_{\mathrm{MSC}}$ were similar in Nebraska. A relatively small $S_{\mathrm{MSC}}$ indicates that the tiller population was comprised of tillers in similar developmental phases, such as the first three harvests for big bluestem in 1990 and 1991 which were comprised solely of vegetative tillers (Fig. 4). The increase in $S_{\mathrm{MSC}}$ as morphological development progressed indicates that the tiller population was comprised of an increasingly diverse array of substages, as illustrated by tiller demographics for the calibration study (Fig. 3 and 4). With intensive grazing management, however, a livestock producer could prevent a large proportion of the tillers from advancing to the reproductive stages and, therefore, maintain a small $S_{\text {MSC. }}$

The quadratic response of big bluestem to GDD across all environments suggests that the morphological development of big bluestem was affected more by environmental variations than was switchgrass (Tables 1 and 2). The linear response of switchgrass MSC to DOY and GDD across all environments indicates that morphological development of switchgrass is highly predictable (Tables 1 and 2), and suggests that switchgrass may be more responsive to photoperiod than big bluestem. Photoperiod response may help explain why more tillers advance to the reproductive stages in switchgrass than in big bluestem.

\section{Prediction of Developmental Morphology}

The calibration equations with the highest correlation coefficients, lowest RMSE, and intercept nearest to 0.0 were selected to predict morphological development of switchgrass and big bluestem (Table 1). Linear and quadratic equations gave the best fit. There was no advantage in using higher order polynomials. Developmental morphology data from Nebraska and Kansas in 1992 and 1993 were used to validate the calibration equations. Actual MSC data were plotted against values predicted from the calibration equation (Table 2). Validation equations would require correlation coefficients equal

Table 1. Calibration equations, coefficients of determination, and root mean square errors (RMSE) for predicting mean stage count (MSC) and mean stage weight (MSW) with accumulated growing degree day (GDD) and day of the year (DOY) for switchgrass and big bluestem grown near Mead, NE, in 1990 and 1991.

\begin{tabular}{|c|c|c|c|}
\hline $\begin{array}{c}\text { Independent } \\
\text { variable }\end{array}$ & Calibration equations & $\begin{array}{l}\text { Coefficient of } \\
\text { determination }\end{array}$ & RMSE \\
\hline \multicolumn{4}{|c|}{ Switchgrass } \\
\hline GDD & $\begin{array}{l}\text { MSC }=0.875+0.0017(\text { GDD }) \\
\text { MSC }=\text { NS } \dagger \\
\text { MSW }=0.832+0.0019(\text { GDD }) \\
\text { MSW }=\mathbf{1 . 1}+\mathbf{0 . 0 0 1 3}(\text { GDD })+0.00000028\left(\text { GDD }^{2}\right)\end{array}$ & $\begin{array}{l}0.98 \\
\overline{0.98} \\
0.98\end{array}$ & $\begin{array}{l}0.10 \\
\overline{0.11} \\
0.11\end{array}$ \\
\hline DOY & $\begin{array}{l}\text { MSC }=-1.399+0.021(\text { DOY }) \\
\text { MSC }=\text { NS } \\
\text { MSW }=-1.736+0.023(\text { DOY }) \\
\text { MSW }=\text { NS }\end{array}$ & $\begin{array}{c}0.94 \\
-\overline{0.94} \\
-\end{array}$ & $\frac{0.16}{0.18}$ \\
\hline \multicolumn{4}{|c|}{ Big bluestem } \\
\hline GDD & $\begin{array}{l}\text { MSC }=0.600+0.0013(\text { GDD }) \\
\text { MSC }=1.178+0.00004(\text { GDD })+0.0000006\left(G^{2} D^{2}\right) \\
\text { MSW }=0.387+0.0017(G D D) \\
\text { MSW }=0.973+0.0005(\text { GDD })+0.0000006\left(G^{2} D^{2}\right)\end{array}$ & $\begin{array}{l}0.86 \\
0.88 \\
0.93 \\
0.94\end{array}$ & $\begin{array}{l}0.20 \\
0.19 \\
0.19 \\
0.17\end{array}$ \\
\hline DOY & $\begin{array}{l}\text { MSC }=-0.978+0.015(\mathrm{DOY}) \\
\text { MSC }=\text { NS } \\
\text { MSW }=-1.875+0.021(\mathrm{DOY}) \\
\text { MSW }=\text { NS }\end{array}$ & $\frac{0.74}{0.84}$ & $\begin{array}{l}0.27 \\
0.28 \\
-\end{array}$ \\
\hline
\end{tabular}

$\dagger$ NS: Addition of the quadratic component was nonsignificant. 
Table 2. Validation equations, coefficients of determination, and root mean square errors (RMSE) for mean stage count (MSC) and mean stage weight (MSW) based on accumulated growing degree day (GDD) and day of the year (DOY) for switchgrass and big bluestem grown near Mead, NE, and Manhattan, KS, in 1992 and 1993.

\begin{tabular}{|c|c|c|c|}
\hline $\begin{array}{c}\text { Independent } \\
\text { variable }\end{array}$ & Regression equations & $\begin{array}{r}\text { Coefficient of } \\
\text { deternination }\end{array}$ & RMSE \\
\hline \multicolumn{4}{|c|}{ Switchgrass } \\
\hline GDD & $\begin{array}{l}\text { MSC }=0.955+0.0019(\text { GDD }) \\
\text { MSC }=0.662+0.0028(\text { GDD })-0.0000006\left(G^{2} D^{2}\right) \\
\text { MSW }=1.035+0.0020(G D D) \\
\text { MSW }=0.673+0.0031(G D D)-0.0000007\left(G^{2} D^{2}\right)\end{array}$ & $\begin{array}{l}0.94 \\
0.95 \\
0.92 \\
0.93\end{array}$ & $\begin{array}{l}\mathbf{0 . 1 8} \\
\mathbf{0 . 1 7} \\
\mathbf{0 . 2 2} \\
\mathbf{0 . 2 0}\end{array}$ \\
\hline DOY & $\begin{array}{l}\text { MSC }=-2.063+0.024(\text { DOY }) \\
\text { MSC }=\text { NS } \dagger \\
\text { MSW }=-2.180+0.025(\text { DOY }) \\
\text { MSW }=\text { NS }\end{array}$ & $\frac{0.96}{0.96}$ & $\frac{0.14}{0.15}$ \\
\hline \multicolumn{4}{|c|}{ Big bluestem } \\
\hline GDD & $\begin{array}{l}\text { MSC }=0.893+0.0011(\text { GDD }) \\
\text { MSC }=1.520-0.00083(\text { GDD })+0.0000012\left(G^{2} D^{2}\right) \\
\text { MSW }=0.841+0.0014(\text { GDD }) \\
\text { MSW }=1.451-0.0004(\text { GDD })+0.0000012\left(G^{2} D^{2}\right)\end{array}$ & $\begin{array}{l}0.75 \\
0.84 \\
0.80 \\
0.85\end{array}$ & $\begin{array}{l}0.24 \\
0.19 \\
0.27 \\
0.23\end{array}$ \\
\hline DOY & $\begin{array}{l}\text { MSC }=-0.745+0.013(\mathrm{DOY}) \\
\text { MSC }=5.88-0.06(\mathrm{DOY})+0.0002\left(\mathrm{DOY}^{2}\right) \\
\text { MSW }=-1.337+0.018(\mathrm{DOY}) \\
\text { MSW }=5.83-0.06(\mathrm{DOY})+0.0002\left(\mathrm{DOY}^{2}\right)\end{array}$ & $\begin{array}{l}0.69 \\
0.79 \\
0.75 \\
0.83\end{array}$ & $\begin{array}{l}0.26 \\
0.22 \\
0.30 \\
0.25\end{array}$ \\
\hline
\end{tabular}

$\dagger$ NS: Addition of the quadratic component was nonsignificant.

to 1.0 , intercept equal to 0.0 , and RMSE equal to 0.0 for perfect fits between predicted and actual values.

The linear DOY and GDD regression equations from the calibration data for switchgrass accounted for 94 and $98 \%$ of the variation in MSC, respectively, and had low RMSE, which indicates strong relationships (Table $1)$. When the validation data were fit to the calibration functions, the linear DOY model gave the best results and accounted for $96 \%$ of the variation in MSC across the four environments (Table 3 ). The linear DOY equation generated from 1990 and 1991 data accurately predicted MSC throughout a range of maturities across all environments (Fig. 6). The high correlation between actual and predicted MSC using the linear DOY model showed that switchgrass development was probably related to photoperiod and that switchgrass management recommendations for adapted cultivars may be made based on DOY in the central Great Plains (Fig. 6).

Table 3. Relationship, coefficients of determination, and root mean square errors (RMSE) between predicted mean stage count (PMSC) and actual MSC and predicted mean stage weight (PMSW) and actual MSW from calibration equations $\dagger$ developed near Mead, NE, in 1990 and 1991 based on accumulated growing degree day (GDD) and day of the year (DOY) for switchgrass and big bluestem and validated with data collected near Mead, NE, and Manhattan, KS, in 1992 and 1993.

\begin{tabular}{|c|c|c|c|}
\hline $\begin{array}{c}\text { Independent } \\
\text { variable }\end{array}$ & $\begin{array}{l}\text { Relationship between } \\
\text { predicted and actual }\end{array}$ & $\begin{array}{l}\text { Coefficient of } \\
\text { determination }\end{array}$ & RMSE \\
\hline \multicolumn{4}{|c|}{ Switchgrass } \\
\hline GDD & $\begin{array}{l}\text { PMSC }=0.157+0.829(\text { MSC) } \\
\text { PMSW }=\mathbf{0 . 0 3 4}+\mathbf{0 . 8 7 9}(\text { MSW })\end{array}$ & $\begin{array}{l}0.94 \\
0.92\end{array}$ & $\begin{array}{l}0.15 \\
0.20\end{array}$ \\
\hline DOY & $\begin{array}{l}\text { PMSC }=0.451+0.826(\text { MSC) } \\
\text { PMSW }=0.349+0.882(\text { MSW })\end{array}$ & $\begin{array}{l}0.96 \\
0.96\end{array}$ & $\begin{array}{l}0.12 \\
0.13\end{array}$ \\
\hline \multicolumn{4}{|c|}{ Big bluestem } \\
\hline GDD & $\begin{array}{l}\text { PMSC }=0.392+0.702(\text { MSC) } \\
\text { PMSW }=0.157+0.825(\text { MSW })\end{array}$ & $\begin{array}{l}0.83 \\
0.84\end{array}$ & $\begin{array}{l}0.15 \\
0.21\end{array}$ \\
\hline DOY & $\begin{array}{l}\text { PMSC }=0.458+0.763(\text { MSC) } \\
\text { PMSW }=0.279+\mathbf{0 . 8 9 2 ( M S W )}\end{array}$ & $\begin{array}{l}\mathbf{0 . 6 8} \\
\mathbf{0 . 7 5}\end{array}$ & $\begin{array}{l}0.24 \\
0.31\end{array}$ \\
\hline
\end{tabular}

$\dagger$ The best calibration equations for MSC and MSW based on GDD and DOY were selected from Table 1.
The big bluestem quadratic GDD regression equation from the calibration study accounted for $88 \%$ of the variation in MSC, and had low RMSE, indicating good relationships between GDD and MSC (Table 1). However, the linear DOY model for big bluestem from the calibration study accounted for only $74 \%$ of the variation (Table 1). When the validation data were fit to the calibration functions, the quadratic GDD equation accounted for $83 \%$ of the variation in MSC across four environments (Fig. 7). The quadratic GDD equation accurately predicted MSC across all environments, with a slope approaching 1.0 and an intercept approaching 0.0 . However, the scattering of points around the regression line at low MSC caused the correlation coefficient to be lower than that for switchgrass (Fig. 7). The MSC of the big bluestem tiller population in the validation study did not progress beyond the mid elongation stages of development, minimizing the range of maturity for prediction. The good correlation between actual and predicted MSC using the quadratic GDD model indicates the feasibility of making big bluestem management

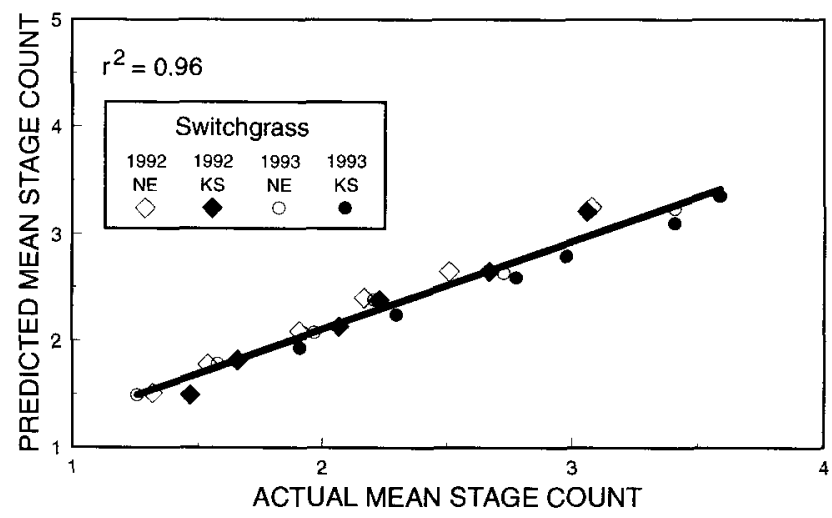

Fig. 6. Relationship between actual mean stage count in four environments and those predicted from a linear day-of-the-year model developed from 'Trailblazer' switchgrass grown near Mead, NE, in 1990 and 1991. 


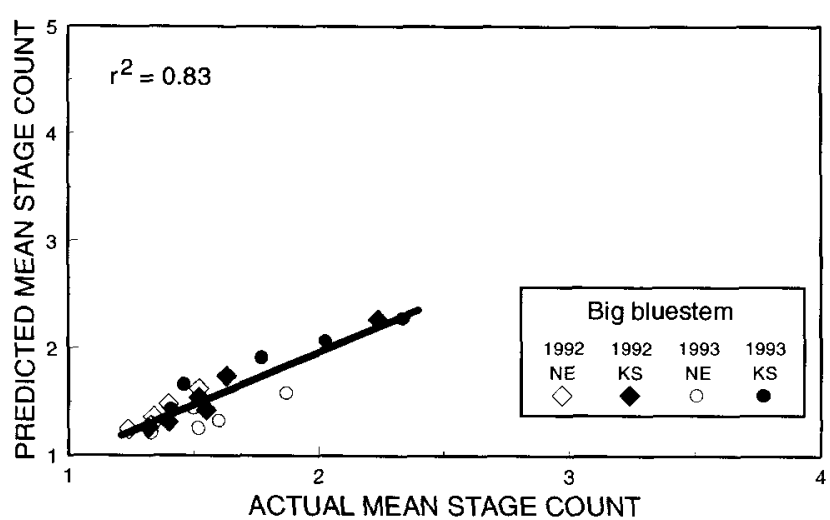

Fig. 7. Relationship between actual mean stage count in four environments and those predicted from a quadratic growing-degree-day model developed from 'Pawnee' big bluestem grown near Mead, NE, in 1990 and 1991.

recommendations across a wide geographic region based on accumulated GDD or the developmental morphology of big bluestem. The morphological development of Trailblazer switchgrass and Pawnee big bluestem can be reliably predicted in the central Great Plains during years with near-normal precipitation using DOY and GDD because of the determinate growth habit of these grasses.

\section{REFERENCES}

Briske, D.D. 1991. Developmental morphology and physiology of grasses. p. 85-108. In R.K. Heitschmidt and J.W. Stuth (ed.) Graz- ing management: An ecological perspective. Timber Press, Portland, $O R$.

Buxton, D.R., and G.C. Marten. 1989. Forage quality of plant parts of perennial grasses and relationship to phenology. Crop Sci. 29:429-435.

Frank, A.B., and L. Hofmann. 1989. Relationship among grazing management, growing degree-days, and morphological development for native grasses on the Northern Great Plains. J. Range Manage. 42:199-202.

Hendrickson, J.R. 1992. Developmental morphology of two Nebraska Sandhills grasses and its relationship to forage quality. M.S. thesis, Univ. of Nebraska, Lincoln.

Kalu, B.A., and G.W. Fick. 1981. Quantifying morphological development of alfalfa for studies of herbage quality. Crop Sci. 21:267-271.

Kirch, B.H. 1995. Rumen escape protein and diet quality of cattle grazing smooth bromegrass, switchgrass, and big bluestem. Ph.D. diss. Univ. of Nebraska, Lincoln (Diss. Abstr. 9536619).

Mitchell, R.B., R.A. Masters, S.S. Waller, K.J. Moore, and L.E. Moser. 1994. Big bluestem production and forage quality responses to burning date and fertilizer in tallgrass prairies. J. Prod. Agric. 7:355-359.

Moore, K.J., and L.E. Moser. 1995. Quantifying developmental morphology of perennial grasses. Crop Sci. 35:37-43.

Moore, K.J., L.E. Moser, K.P. Vogel, S.S. Waller, B.E. Johnson, and J.F. Pedersen. 1991. Describing and quantifying growth stages of perennial forage grasses. Agron. J. 83:1073-1077.

Moser, L.E., and K.P. Vogel. 1995. Switchgrass, big bluestem, and indiangrass. p. 409-420. In R.F Barnes et al. (ed.) Forages: An introduction to grassland agriculture. 5th ed. Iowa State Univ. Press, Ames.

Nelson, C.J., and L.E. Moser. 1994. Plant factors affecting forage quality. p. 115-154. In G.C. Fahey, Jr., et al. (ed.) Forage quality, evaluation, and utilization. ASA, CSSA, and SSSA, Madison, WI.

Rehm, G.W., R.C. Sorensen, and W.J. Moline. 1976. Time and rate of fertilizer application for seeded warm-season and bluegrass pastures: I. Yield and botanical composition. Agron. J. 68:759-764.

SAS Institute. 1985. SAS user's guide: Statistics. Version 5 ed. SAS Inst., Cary, NC. 